\title{
PENGEMBANGAN MEDIA PEMBELAJARAN INTERAKTIF BERBASIS PENELITIAN EFEK EKSTRAK DAUN Tithonia diversifolia TERHADAP KADAR GLUKOSA DARAH TIKUS WISTAR
}

\author{
Fithri Wening Sasmita ${ }^{1}$ \\ Eko Susetyarini $^{2}$ \\ Husamah $^{3}$ \\ Yuni Pantiwati ${ }^{4}$ \\ $1,2,3,4)$ \\ Pendidikan Biologi FKIP Uni versitas Muhammadi yah Malang \\ E-mail: fitri.sasmita23@yahoo.com,niniek08@g mail.com,usya_bio@yahoo.com, \\ yuni.pantiwati@yahoo.co.id

\begin{abstract}
This research is a kind of Research and Development Learning Cycle $3 E$ Model (Exploration, Explanation, and Elaboration). Results of research on the effects of dosing leaf extract flower moon (Tithonia diversifolia) to decrease blood glucose levels in wistar rats induced by alloxan obtained from experimental studies used as the material for developing interactive learning media on the matter Structure and Function of Cells Composer tissue in the digestive system (Biology, Senior High School, Grade XI, Basic Competency 3.7). The research was conducted from March to August 2016 at the University of Muhammadiyah Malang. Interactive learning media that has been developed consisting of a variety of menus, namely, 1) Title of matter, namely the structure and function of cells making up the network on the digestive system; 2) Present the student competence unbiased KI, KD, indicators; 3) Presenting materials about digestive tools, digestive gland, video digestive process, digestive disorders, diabetes mellitus, and plant Tithonia diversifolia; 4) Problem evaluation; 5) referral sources; 6) The results of the study, and 7) Profile of developers and lecturers.
\end{abstract}

Kata kunci: diabetes, media, interactive, Sen ior High School, Thitonia

Diabetes Mellitus (DM) adalah penyakit metabolik yang dapat ditandai kenaikan kadar gula darah atau hiperglikemia kronik (Powers, 2001). DM menjadi penyakit global endemik (Shaw et al., 2010) dan masalah kesehatan utama dunia (Dodie et al., 2013). Indonesia menduduki posisi keempat dalam jumlah penderita DM terbanyak di dunia setelah India, Cina, dan Amerika Serikat (Wiryowidagdo, 2002; Wild et al., 2004).

Penyakit DM beserta tren perkembangan cara atau metode pengobatannya adalah isu aktual dan kontekstual dunia secara umum dan Indonesia secara khusus, yang harus direspon juga oleh dunia pendidikan. Pembelajaran di sekolah memiliki peran sangat penting dalam mengembangkan kompetensi peserta didik. Peran penting sekolah tersebut tidak hanya dalam peran mentransfer ilmu pengetahuan dan mengajarkan nilai-nilai dalam kehidupan seharihari saja, tetapi juga peran sekolah dalam peningkatan pengetahuan secara luas dan mendunia. Sehubungan dengan itu, tujuan pembelajaran di sekolah salah satunya adalah mempersiapkan para siswa menghadapi dunia global dan perkembangan kehidupan di sekitarnya. 
Menurut Alvioriki (2015) materi yang disampaikan guru harus bertujuan membekali siswa untuk dapat mengaplikasikan ilmu dalam kehidupan. Hal ini sejalan dengan Nurohman (2006) bahwa nilai intelektualitas Biologi menuntut kecerdasan dan ketekunan dalam mencari jawaban suatu persoalan didasarkan atas pertimbangan rasional dan objektif. Biologi dengan segala isi dan karakternya, memberikan sumbangan lebih nyata terhadap siswa agar memiliki bekal memadai untuk bertahan hidup di masyarakat. Biologi senantiasa berdekatan dengan realitas alam yang menjadi tempat hidup siswa.

$$
\text { Pembelajaran biologi di }
$$
sekolah umumnya masih sering dilakukan dengan hanya menggunakan sumber belajar berupa buku-buku penunjang, padahal materi biologi tidak seluruhnya dapat diperoleh dari buku-buku tersebut tetapi juga dari berbagai kondisi di lingkungan, artikel, berbagai hasil penelitian dan ditunjang media pembelajaran yang sesuai. Fenomenafenomena yang terjadi di sekitarpun dapat dijadikan sebagai sumber belajar (Alvioriki, 2015). Hal ini misalkan dalam dunia kesehatan yaitu penyakit DM dan pemanfaatan keanekaragaman tumbuhan untuk pengobatannya.

Salah satu mata pelajaran yang terkait dengan DM adalah Biologi SMA kelas XI pada KD 3.7 yaitu menganalisis hubungan antara struktur jaringan penyusun organ pada sistem pencernaan dan mengaitkannya dengan nutrisi dan bioprosesnya sehingga dapat menjelaskan proses pencernaan serta gangguan fungsi yang mungkin terjadi pada struktur dan fungsi sel penyusun jaringan pada sistem pencernaan melalui studi literatur, pengamatan, percobaan, dan simulasi. Hasil penelitian terkait yang dikemas dalam media pembelajaran interaktif diharapkan dapat memberikan manfaat bagi siswa, yaitu menambah informasi, pengetahuan, dan keterampilan dalam menjaga tubuh agar terhindar dari DM dan memanfaatkan berbagai potensi tumbuhan obat di sekitarnya untuk pengobatan DM. Berdasarkan berbagai uraian di atas maka perlu kiranya dilakukan penelitian untuk membuktikan adanya pengaruh ekstrak daun kembang bulan (Tithonia diversifolia) terhadap penurunan kadar glukosa darah tikus wistar (Rattus norvegicus) dan pengembangannya sebagai media pembelajaran interaktif.

Inovasi yang dapat digunakan untuk meningkatkan kualitas pembelajaran dengan pembuatan media interaktif yang memanfaatkan Software Flash. Flash adalah program grafis yang diproduksi pertama kali oleh Macromedia corp, yaitu sebuah vendor software yang bergerak dibidang animasi web (dikenal dengan Macromedia Flash). Flash pertama kali diproduksi pada tahun 1996. Versi terakhir dari Macromedia adalah Macromedia Flash 8. Saat ini Flash telah berpindah vendor ke Adobe (disebut Adobe Flash). Semua tools masih sama, yang membedakan adalah adanya jenis Actionsript 3.0. (Izham, 2012).

Menurut Waryanto (2005) Flash merupakan program aplikasi standar authoring tool profesional yang digunakan untuk membuat animasi vektor dan bitmap untuk membuat media interaktif, menarik, dan dinamis. Software ini berbasis animasi vektor yang dapat digunakan 
untuk menghasilkan animasi web, presentasi, game, film, maupun CD interaktif, dan CD pembelajaran. Objek-objek yang dapat diolah untuk membuat animasi selain gambar vektor (yang dibuat langsung dari Flash) juga gambar-gambar bitmap yang diimpor, objek sound dan objek avi. Untuk menjalankan animasi diperlukan software salah satunya adalah program Flash.

Animasi yang dihasilkan flash adalah animasi berupa file movie yang dapat berupa grafik atau teks. Grafik yang dimaksud disini adalah grafik yang berbasis vektor, sehingga saat diakses melalui internet, animasi akan ditampilkan lebih cepat dan terlihat halus. Selain itu flash juga memiliki kemampuan untuk mengimpor file suara, video maupun file gambar dari aplikasi lain (Izham, 2012).

Kelebihan Flash adalah dapat menganimasikan gambar dengan baik, mampu memproses keluar gambar dan suara yang dinamis, mampu mendesain untuk berbagai media, dan dapat menambahk an suara deskripsi dari suatu animasi. Kelemahan dari pembuatan media dengan Flash ini adalah memerlukan komputer atau laptop yang sudah ada program Flash sehingga tidak dapat digunakan tanpa adanya program tersebut dan diperlukan ketrampilan khusus untuk dapat menggunakan software tersebut (Suciadi, 2003).

Berdasarkan latar belakang yang telah diuraikan di atas, maka penelitian ini bertujuan mengimplementasikan hasil penelitian tentang pengaruh ekstrak daun kembang bulan (Tithonia diversifolia) terhadap penurunan kadar glukosa darah tikus putih wistar ini sebagai media pembelajaran interaktif.

\section{METODE \\ Jenis Penelitian}

Penelitian ini adalah jenis pengembangan model Learning Cycle $3 E$ (Eksplorasi, Eksplanasi, dan Elaborasi). Hasil penelitian mengenai efek pemberian dosis ekstrak daun $T$. diversifolia terhadap penurunan kadar glukosa darah pada tikus wistar yang diinduksi Alloxan yang diperoleh dari penelitian eksperimen dijadikan materi untuk mengembangkan media. Pengembangan dilakukan pada materi Struktur dan Fungsi Sel Penyusun Jaringan pada Sistem Pencernaan (Mata Pelajaran Biologi SMA Kelas XI, Kompetensi Dasar 3.7).

\section{Tempat dan Waktu Penelitian}

Penelitian ini dilaksanakan pada bulan Maret sampaidengan Agustus 2016 di Universitas Muhammadiyah Malang.

\section{Prosedur Penelitian}

Prosedur penelitian ini meliputi persiapan penelitian dan kemudian dilanjutkan dengan pelaksanaan kegiatan pengembangan.

\section{Persiapan Penelitian}

Persiapan penelitian ini, yaitu persiapan alat/instrumen dan bahan pembuatan media pembelajaran interaktif. Adapun alat/instrumen adalah laptop, dan Software Adobe Flash player. Bahan penelitian ini adalah 1) data hasil penelitian tahap I, 2) Silabus SMA kelas XI, 3) Materi pembelajaran biologi SMA dari buku, jurnal, dan internet, serta 4) Soal evaluasi pembelajaran materi.

\section{Pelaksanaan Penelitian}

Hasil penelitian eksperimen yang telah diperoleh dikembangkan menjadi sebuah produk media 
pembelajaran interaktif pada materi Struktur dan Fungsi Sel Penyusun Jaringan pada Sistem Pencernaan kelas XI SMA dengan menggunakan model Learning Cycle $3 E$ yang dimodifikasi ke dalam penelitian pengembangan. Menurut Fajaroh \& Dasna (2007) model Learning Cycle adalah model yang terdiri fase-fase atau tahap-tahap kegiatan yang diorganisasikan sedemikian rupa sehingga dapat menguasai kompetensi-kompetensi yang harus dicapai dalampembelajaran dengan jalan berperan aktif. Learning Cycle dalam pandangan Doğru-Atay \& Tekkaya (2008) membantu untuk membangun pengetahuan yang baru dengan membuat perubahan secara konseptual melalui interaksi dengan lingkungan dan dunia nyata.

Penelitian ini hanya sampai pada tahap validasi produk karena dasar metode Learning Cycle 3-E tidak ada uji coba produk berupa yang dihasilkan. Tahap Learning Cycle 3-E dimodifikasi dari Wena (2011) sebagai berikut:

\section{Eksplorasi}

Eksplorasi merupakan fase pengumpulan data atau analisis kebutuhan (need assesment) sesuai dengan kebutuhan pengembangan. Pengumpulan data dapat diperoleh dari hasil penelitian, silabus, Rancangan Pelaksanaan Pembelajaran (RPP), guru maupun siswa. Data yang dikumpulkan melalui analisis kebutuhan merupakan kebutuhan pengembangan atau kebutuhan konsep esensial. Pengumpulan data dalam penelitian ini diperoleh dari hasil penelitian eksperimen, buku biologi SMA, dan silabus SMA.

Hasil penelitian eksperimen, yaitu efek pemberian dosis ekstrak daun kembang bulan terhadap penurunan kadar glukosa darah pada tikus wistar yang diinduksi dengan Alloxan. Buku pelajaran Biologi SMA kelas XI mengenai materi Struktur dan Fungsi Sel Penyusun Jaringan pada Sistem Pencernaan. Silabus SMA kelas XI Kurikulum 2013, pada KD 3.7 yaitu "Menganalisis hubungan antara struktur jaringan penyusun organ pada sistem pencernaan dan mengaitkannya dengan nutrisi dan bioprosesnya sehingga dapat menjelaskan proses pencernaan serta gangguan fungsi terjadi pada struktur dan fungsi sel penyusun jaringan pada sistem pencernaan melalui studi literatur, pengamatan, percobaan, dan simulasi”.

Kebutuhan esensial yang diperoleh pada tahap analisis kebutuhan dari hasil penelitian tahap I, buku pelajaran dan silabus, yaitu a) struktur dan fungsi sel penyusun jaringan sistem pencernaan makanan manusia; b) struktur sel penyusun jaringan pencernaan dan mengaitkan dengan fungsinya; c) mekanisme pencernaan makanan pada tubuh manusia; d) penyakit atau gangguan bioproses sistem pencernaan, e) tinjauan tentang DM, f) tinjauan tentang Tithonia diversifolia, dan g) hasil penelitian.

\section{Eksplanasi}

Fase ini bertujuan melengkapi, menyempurnakan, dan mengembangkan konsep yang diperoleh dari fase sebelumnya. Konsep yang telah diperoleh diuraikan berdasarkan kajian pustaka dan dikonsultasikan dengan pembimbing sehingga menjadi konsep esensial. 


\section{Elaborasi}

Elaborasi merupakan tahap pembuatan produk, dihasilkan produk yang dihasilkan berupa media pembelajaran interaktif untuk siswa SMA kelas XI materi Struktur dan Fungsi Sel Penyusun Jaringan pada Sistem Pencernaan. Langkah-langkah pembuatan media pembelajaran interaktif, sebagai berikut, 1) Menyiapkan konsep-konsep esensial yang telah dikembangkan dari sumber pustaka. 2) Merancang desain media pembelajaran interaktif sesuai dengan konsep esensial yang didapat dan dikembangkan melalui studi pustaka.

3) Menginputkan konsep esensial (materi, hasil penelitian dan gambargambar) pada lembar kerja Adobe Flash dan menambahkan teks untuk memberi penjelasan atau keterangan.

4) Menambahkan soal evaluasi pembelajaran materi bahan kimia dalam kehidupan dan menentukan scoring. 5) Menyimpan atau mempublish media dengan format (exe).

\section{HASIL}

Hasil penelitian tentang pengaruh ekstrak daun $T$. diversifolia terhadap penurunan kadar glukosa darah tikus putih wistar ini diimplementasikan sebagai media pembelajaran interaktif. Pada tahap pengembangan diperoleh draft produk awal dalam bentuk storyboard yang digunakan panduan pengembangan media pembelajaran interaktif berbentuk Adobe Flash. Berikut adalah visualisasi produk multimedia interaktif menggunakan Adobe Flash pada materi Struktur dan Fungsi Sel Penyusun Jaringan pada Sistem Pencernaan (Mata Pelajaran Biologi SMA Kelas XI, KD 3.7) ditunjukkan pada Gambar 1 sampai Gambar 15.

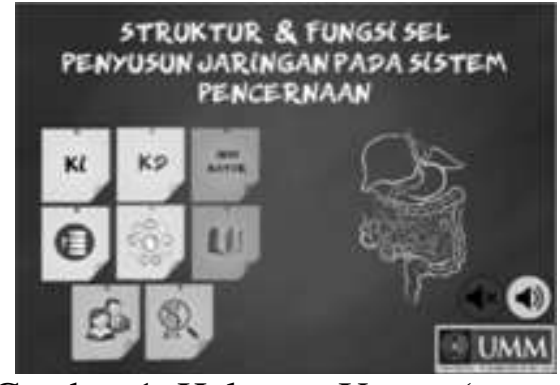

Gambar 1. Halaman Utama (cover)

Gambar 1 merupakan halaman utama yang terdiri dari 1) judul materi yaitu struktur dan fungsi sel penyusun jaringan pada sistem pencernaan; 2) menu utama yang meliputi: KI, KD, indikator, materi, soal evaluasi, sumber rujukan, hasil penelitian, dan profil yang dapat dik lik untuk melihat penjelasan; 3) gambar organ sistem pencernaan; 4) tombol play dan stop musik; dan 5) logo UMM.

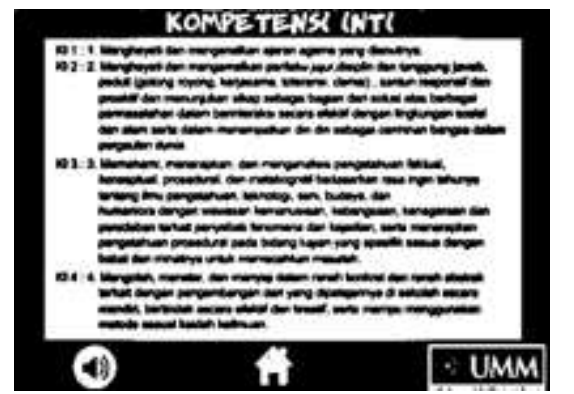

Gambar 2. Halaman Kompetensi Inti

Gambar 2 merupakan halaman kompetensi inti yang terdiri dari 1) Tulisan kompetensi inti dengan animasi kapur; 2) penjabaran dari kompetensi inti 1 sampai dengan kompetensi inti 4; 3) tombol home untuk kembali ke menu utama; 4) tombol play dan stop musik yang dapat diklik; dan 5) logo UMM. 


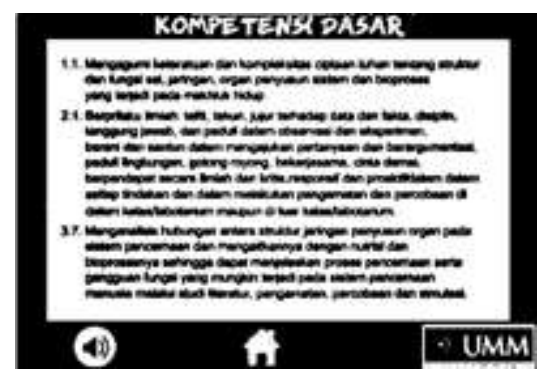

Gambar 3. Halaman Kompetensi Dasar

Gambar 3 merupakan halaman KD yang terdiri dari 1) Tulisan kompetensi dasar dengan animasi kapur; 2) penjabaran dari kompetensi dasar 1.1, 2.1, dan 3.7;3) tombol home untuk kembali ke menu utama; 4) tombol play dan stop musik yang dapat dik lik; dan 5) logo UMM .

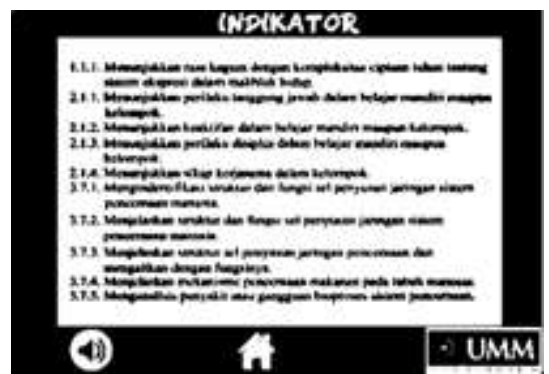

Gambar 4. Halaman Indikator

Gambar 4 merupakan halaman inidikator yang terdiri dari 1) Tulisan indikator dengan animasi kapur; 2) penjabaran dari indikator 1.1.1, 2.1.1, 2.1.2, 2.1.3, 2.1.4, 3.7.1, 3.7.2, 3.7.3, 3.7.4, dan 3.7.5; 3) tombol home untuk ke menu utama; 4) tombol play dan stop musik yang dapat diklik; dan 5) logo UMM.

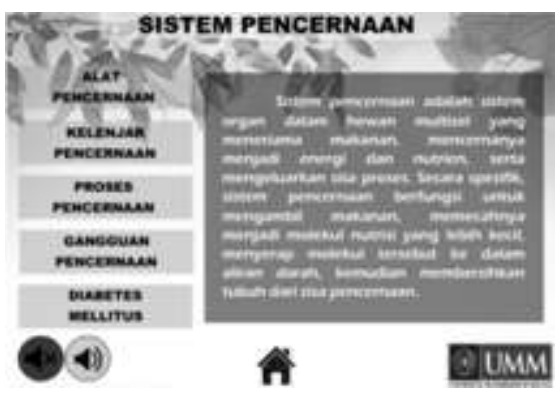

Gambar 5. Halaman Materi
Gambar 5. merupakan halaman materi, terdiri dari 1) Tulisan sistem pencernaan; 2) menu sub bab yang dapat diklik untuk melihat penjabaran masing-masing menu sub bab (alat pencernaan, kelenjar pencernaan, proses pencernaan, gangguan pencernaan, dan diabetes mellitus0; 3) penjelasan mengenai sistem pencernaan; 4) tombol home untuk kembali ke menu utama 4) tombol play dan stop musik yang dapat diklik; dan 5) logo UMM, terletak di sebelah kiri bawah.

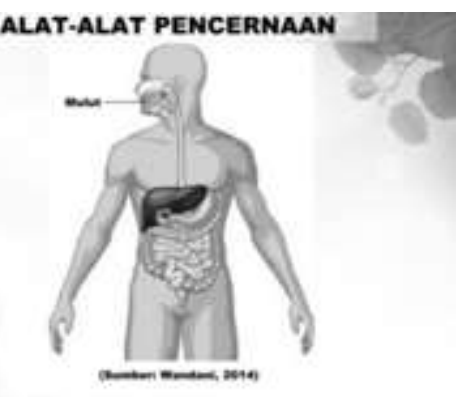

Gambar 6. Halaman Sub Bab Alat-alat Pencernaan

Gambar 6 merupakan halaman sub bab alat-alat pencernaan yang terdiri dari 1) Tulisan alat-alat pencernaan; 2) gambar animasi organ pencernaan manusia beserta keterangan alat-alat pencernaan yang dapat bergerak layaknya proses pencernaan meliputi: mulut, kerongkongan, lambung, usus halus, usus besar, rectum, dan anus; 3) tombol next yang dapat diklik untuk melanjutkan ke materi selanjutnya; dan 4) tombol home untuk kembali ke menu utama. 


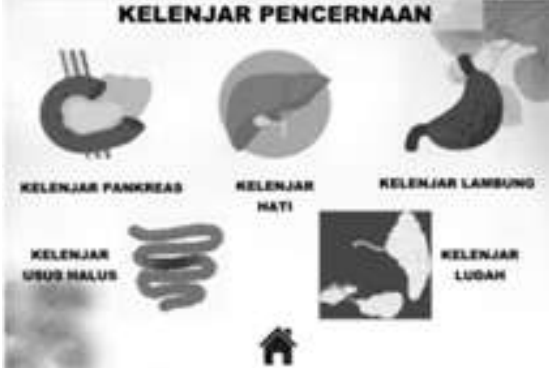

Gambar 7. Halaman Sub Bab Kelenjar

Pencernaan

Gambar 7 merupakan halaman sub bab kelenjar pencernaan yang terdiri dari 1) Tulisan kelenjar pencernaan; 2) gambar animasi kelenjar pencernaan terdiri dari: kelenjar pankreas, kelenjar hati, kelenjar lambung, kelenjar usus halus, dan kelenjar ludah yang dapat diklik untuk melihat penjelasan dari masingmasing gambar kelenjar tersebut; 3) tombol home kembali ke menu utama.

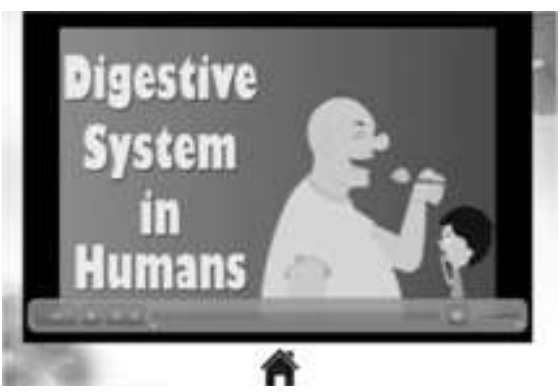

Gambar 8. Halaman Sub Bab Proses Pencernaan

Gambar 8 merupakan halaman sub bab proses pencernaan yang terdiri dari 1) video animasi yang dilengkapi dengan suara yang menjelaskan tentang proses pencernaan dan penjelasan dari suara tersebut dalam bahasa Indonesia dan bahasa Inggris; 2) pada video tersebut dilengkapi dengan tombol play, stop, next, back, dan volume suara; dan 3) tombol home untuk kembali ke menu utama.

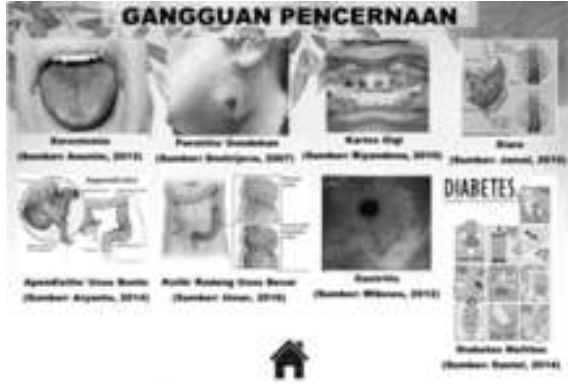

Gambar 9 Halaman Sub Bab Gangguan Pencernaan

Gambar 9 merupakan halaman sub bab gangguan pencernaan yang terdiri dari 1) Tulisan gangguan pencernaan; 2) beberapa gambar contoh gangguan pencernaan beserta keterangannya; 3) tombol home untuk kembali ke menu utama.

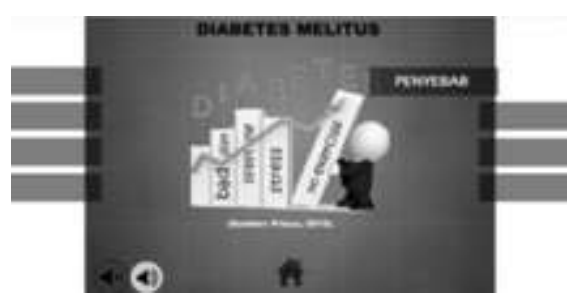

Gambar 10. Halaman Sub Bab DM

Gambar 10 merupakan halaman sub bab diabetes mellitus yang dapat dipilih dan diklik untuk melihat penjelasan, gambar, grafik, dan tabel dari masing masing isi tersebut yang terdiri atas 1) pengertian, klasifikasi, gejala \& tanda, diagnosis, penyebab, komplikasi, pengobatan, dan mekanisme; 2) terdapat gambar gejala \& tanda pada diabetes mellitus; 3) tombol play dan stop musik yang dapat diklik; dan 4) logo UMM. 


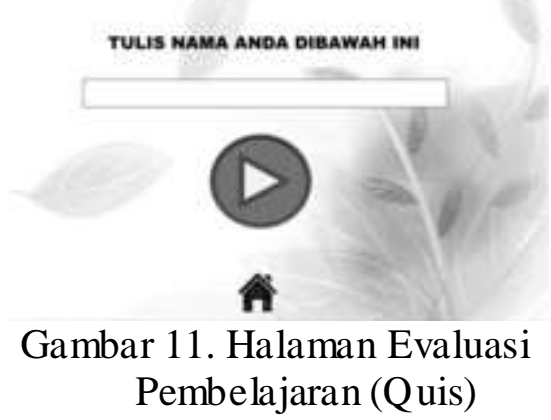

Gambar 11 merupakan halaman evaluasi pembelajaran (quis) yang terdiri atas 1) tulisan tulis nama anda dibawah ini 2) kotak untuk mengisi nama 3) tombol play yang artinya mulai mengerjakan soal latihan berupa pilihan ganda, uraian singkat, memilih dan mencocokan gambar, dan menyebutkan nama organ yang di tunjukkan anak panah; 4) tombol home untuk kembali ke menu utama; dan 5) terdapat musik ketika siswa mulai mengerjakan quis.

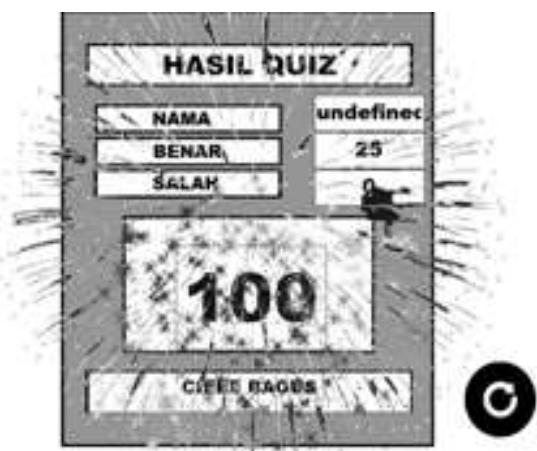

Gambar 12. Halaman Hasil Quis

Gambar 12 merupakan halaman hasil quis dengan nilai yang diperoleh, terdiri atas 1) tulisan hasil quis; 2) kolom untuk mengisi nama, skor benar, skor salah; 3) kolom hasil skor akhir; 4) kolom komentar; 5) animasi percikan kembang api (jika nilai bagus) atau animasi hujan dan emoticon menangis (jika nilai tidak bagus); dan 6) tombol untuk mengulang mengerjakan soal kembali.

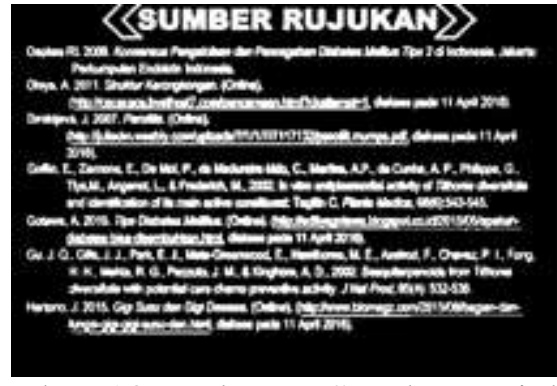

Gambar 13. Halaman Sumber Rujukan

Gambar 13 merupakan sumber rujukan yang terdiri atas 1) tulisan sumber rujukan; 2) tombol next untuk melanjutkan halaman berikutnya; 3) tombol back untuk kembali ke halaman sebelumnya; 4) berbagai sumber rujukan; 5) tombol home untuk kembali ke menu utama.

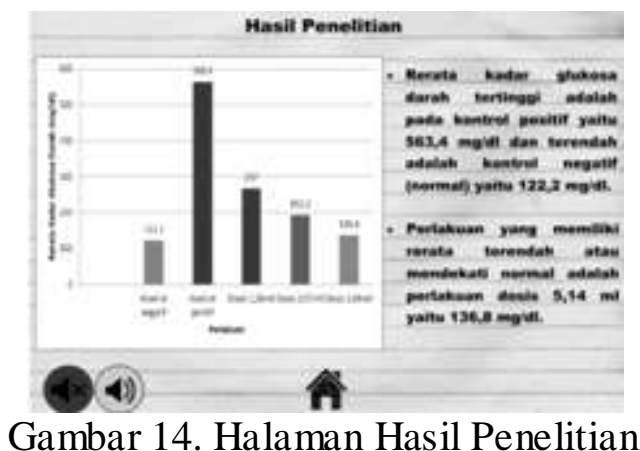

Gambar 14 merupakan halaman hasil penelitian yang terdiri dari 1) tulisan hasil penelitian; 2) grafik rerata kadar glukosa darah tikus wistar; 3) penjelasan grafik; 4) tombol next untuk melanjutkan halaman berikutnya; 5) tombol back untuk kembali ke halaman sebelumnya; 5) tombol play dan stop musik yang dapat diklik; dan 6) logo UMM. 


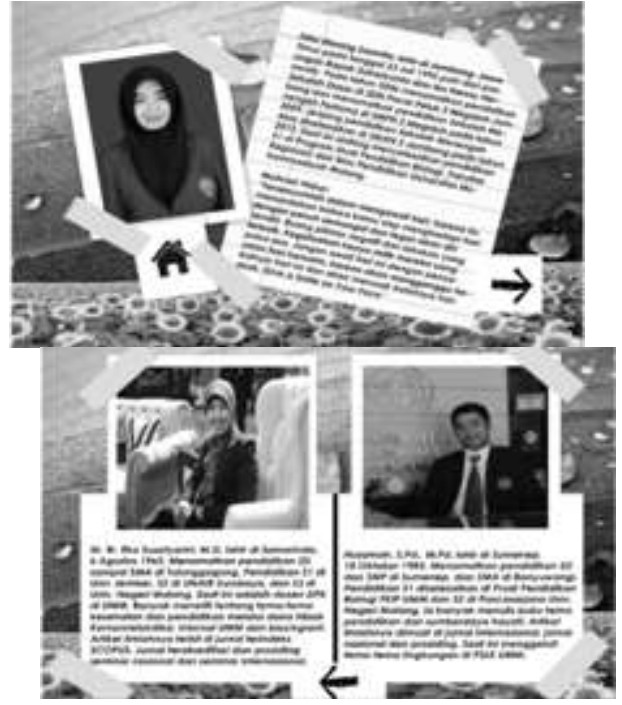

Gambar 15. Halaman Profil Pengembang dan Dosen Pembimbing

Gambar 15 merupakan halaman profil pengembang dan dosen pembimbing yang terdiri atas 1) foto, biodata, dan motivasi hidup; 2) tombol next untuk melanjutkan halaman berikutnya; 3) tombol back untuk kembali ke halaman sebelumnya; dan 4) tombol home untuk kembali ke menu utama.

\section{PEMBAHASAN}

Hasil penelitian tentang pengaruh ekstrak daun $T$. diversifolia terhadap penurunan kadar glukosa darah tikus wistar telah dikembangkan menjadi media pembelajaran interaktif sehingga diharapkan dapat diterapkan di jenjang pendidikan SMA. Menurut Sanaky (2009) media pembelajaran adalah sarana pendidikan yang dapat digunakan sebagai perantara dalam proses pembelajaran untuk mempertinggi efektivitas dan efisiensi dalam mencapai tujuan pengajaran. Penggunaan media yang sesuai dapat meningkatkan hasil belajar siswa, serta dapat meningkatkan motivasi siswa dalam proses pembelajaran.

\begin{tabular}{lrr}
\multicolumn{2}{c}{ Pengembangan } & hasil \\
penelitian & menjadi & media \\
pembelajaran & interaktif & diharapkan
\end{tabular} dapat membangkitkan keinginan dan minat siswa dalam belajar biologi khususnya pada KD dan indikator terkait, membangkitkan motivasi dan rangsangan kegiatan belajar, dan bahkan membawa pengaruh positif terhadap psikologis siswa. Hal ini sejalan dengan Arsyad (2011) bahwa fungsi media pembelajaran diantaranya 1) memperjelas penyajian pesan dan informasi sehingga dapat memperlancar dan meningkatkan proses dan hasil belajar; 2) meningkatkan motivasi dan efisiensi penyampaian informasi; 3) meningkatkan efektivitas dan efisiensi penyampaian informasi 4) menambah variasi penyajian materi; 5) pemilihan media yang tepat akan menimbulkan semangat, gairah, dan mencegah kebosanan siswa untuk belajar; 6) kemudahan materi untuk dicerna dan lebih membekas, sehingga tidak mudah dilupakan siswa; 7) memberikan pengalaman yang lebih kongkrit bagi hal yang mungkin abstrak; 8) meningkatkan keingintahuan siswa; 9) memberikan stimulus dan mendorong respon siswa.

Pengembangan dan penggunaan multimedia pembelajaran secara tepat dan baik, akan memberi manfaat yang besar bagi guru dan peserta didik. Secara umum manfaat yang diperoleh proses pembelajaran lebih menarik, lebih interaktif, jumlah waktu mengajar dapat dikurangi, kualitas belajar peserta didik dapat ditingkatkan dan proses belajar mengajar dapat dilakukan dimana dan kapan saja, serta sikap belajar peserta didik dapat ditingkatkan (Sadiman $e t$ al., 2002).

Media pembelajaran interaktif yang dikembangkan menggunakan software Adobe Flash. Menurut Tjiptono (2011) mengemukakan 
bahwa karakteristik dari media animasi flash, yaitu 1) Software design animasi; 2) Dapat dijalankan pada sistem operasi Windows XP, Windows 7 dan versi terbaru; 3) Mudah digunakan atau dioperasikan; 4) Salah satu software design multimedia pembelajaran interaktif; dan 5) Salah satu design multimedia pembelajaran presentasi animasi yang menarik. Sejalan dengan itu, menurut Sewell et al (1995) media Adobe Flash merupakan media yang tepat untuk membuat berbagai sajian visual yang dapat menginterpretasikan berbagai media, seperti video, animasi, gambar, dan suara, sehingga program ini cukup handal dalam pembuatan berbagai macam aplikasi tutorial yang interaktif dan menarik. Software multimedia komputer telah digunakan untuk mengganti praktek menggunakan hewan. Teknologi ini menggambarkan sebuah alat bantu mengajar yang lebih baik untuk ilmu pengetahuan dibidang biologi.

Pengembangan

hasil penelitian ini menjadi media pembelajaran interaktif diharapkan dapat mengatasi permasalahan siswa dalam belajar topik ini. Menurut Harahap et al (2015) kesulitan siswa dalam memahami pelajaran tersebut pada materi sistem pencernaan makanan manusia, yang menjadi patokan penting dalam menjaga kesehatan dalam kehidupan. Media yang selama ini digunakan masih berpatokan dengan PowerPoint. Media PowerPoint yang disusun oleh guru masih pasif sehingga siswa kurang aktif untuk memahami materi pelajaran di kelas. Misalnya dengan topik pembelajaran sistem pencernaan makanan pada manusia yang membutuhkan animasi yang dapat meningkatkan pemahaman siswa tentang proses terjadi sistem tersebut dalam skema pembelajaran. Oleh sebab itu, siswa sangat membutuhkan media ajar yang interaktif berupa animasi sehingga dapat memudahkan siswa untuk belajar.

Media pembelajaran interaktif yang telah dikembangkan terdiri dari berbagai menu yaitu, 1) Judul materi yaitu struktur dan fungsi sel penyusun jaringan pada sistem pencernaan; 2) Menyajikan kompetensi siswa berisi $\mathrm{KI}$, KD, indikator; 3) Menyajikan materi tentang alat-alat pencernaan, kelenjar pencernaan, video proses pencernaan, gangguan pencernaan, diabetes mellitus, dan tanaman $T$. diversifolia; 4) Soal evaluasi; 5) Sumber rujukan; 6) Hasil penelitian, dan 7) Profil pengembang.

Materi yang dimasukkan kedalam media ini telah sesuai dengan kebutuhan indikator dan materi biologi yang diajarkan di sekolah SMA kelas XI. Langkah serupa juga dilakukan oleh Harahap et al (2015) yang mengembangkan menu sebagai berikut: 1) Pendahuluan berisi gambar intro dan bahasa interaktif; 2) Menu utama terdapat materi pelajaran dan tombol navigasi; 3) Menyajikan Kompetensi Siswa berisi SK dan KD, Indikator, serta Tujuan Pembelajaran; 4) Menyajikan Materi Sistem Pencernaan Makanan; 5) Video Pembelajaran berisi proses pencernaan; 6) Glosarium; 7) Latihan Soal; 8) Daftar Pustaka, gambar dan animasi yang digunakan untuk menyusun media; dan 9) Biodata Pembuat Media.

\section{KESIMPULAN}

Berdasarkan hasil dan pembahasan yang telah dilakukan maka kesimpulan penelitian ini Media pembelajaran interaktif yang telah dikembangkan terdiri dari berbagai 
menu yaitu, 1) Judul materi yaitu struktur dan fungsi sel penyusun jaringan pada sistem pencernaan; 2) Menyajikan kompetensi siswa berisi $\mathrm{KI}$, KD, indikator; 3) Menyajikan materi tentang alat-alat pencernaan, kelenjar pencernaan, video proses pencernaan, gangguan pencernaan, diabetes mellitus, dan tanaman Tithonia diversifolia; 4) Soal evaluasi; 5) Sumber rujukan; 6) Hasil penelitian, dan 7) Profil pengembang dan dosen pembimbing.

\section{SARAN}

Saran yang dapat diberikan berdasarkan kesimpulan penelitian di atas adalah Guru Biologi SMA Kelas XI dapat menggunakan media pembelajaran interaktif yang telah dikembangkan, sehingga memperkaya materi yang disampaikan dalam pembelajaran di sekolah (di kelas maupun di laboratorium saat praktikum). Penggunaan media dapat dilakukan dengan terlebih dahulu melakukan validasi dan ujicoba terbatas.

\section{DAFTAR RUJUKAN}

Alvioriki, D. 2015. Pengaruh Konsentrasi Jus Semangka (Citrullus vulgaris) terhadap penurunan Kadar Gula Darah pada Mencit (Mus muscullus) Diabetes Mellitus (sebagai Alternatif Sumber Belajar Biologi SMA Kelas XII pada materi Pembelajaran Sistem Sirkulasi pada Manusia). Skripsi tidak diterbitkan. Yogyakarta: Prodi Pendidikan Biologi FKIP UAD.

Arsyad, A. 2011. Media Pembelajaran. Jakarta: PT Grafindo.

Dodie, N. J., Tendean, L. \& Wantouw, B. 2013. Pengaruh
Lamanya Diabetes Mellitus Terhadap Terjadinya Disfungsi Ereksi. Jurnal e-Biomedik (eBM), 1(3): 1120-1125.

Doğru-Atay, P. \& Tekkaya, C. 2008. Promoting Students' Learning in Genetics through Learning Cycle.Journal of Experimental Education, 76 (2008): 259-280.

Fajaroh, F \& Dasna, I., W. 2007. Model-Model Pembelajaran Inovatif. Malang: Lembaga Pengembangan Pendidikan dan Pembelajaran Universitas Negeri Malang.

Harahap, H.S., Hasruddin \& Djulia, E. 2015. Pengembangan Media Ajar Interaktif Biologi Berbasis Macromedia Flash pada Materi Sistem Pencernaan Makanan Manusia untuk Kelas XI SMA/MA. Seminar Nasional XII Pendidikan Biologi FKIP UNS 2015.

Izham, D. 2012. Cara Cepat Belajar Adobe Flash. Jakarta: Komunitas eLearning IlmuKomputer.Com.

Nurohman, S. 2006. Penerapan Pendekatan Sains Teknologi Masyarakat (STM) dalam Pembelajaran IPA sebagai Upaya Peningkatan Life Skills Peserta Didik. Majalah Ilmiah Pembelajaran, 2(1).

Powers, A. 2001. Dibetes Mellitus. Dalam Braunwald, E., Fauci, A., Kasper, D., Hauser, S., Longo, D. \& Jameson, J. Harrison's Principles of Internal Medicine. $15^{\text {th }}$ Edition. New York: McGraw-Hill.

Sadiman. 2006. Media Pendidikan. Jakarta: Rajawali Pers.

Sanaky, H. A. H. 2009. Media Pembelajaran. Yogyakarta: Safiria Insania Press. 
Sewell, R. Stevens., R. \& David., J. A. L. 1995. Multimedia Computer Technology as a Tool for Teaching and Assessment of Biological Science. Journal of Biological Education, 29(4): 27-32.

Shaw, J. E., Sicre, R. A. \& Zimmet, P. Z. 2010. Global estimates of theprevalence of diabetes for 2010 to 2030. Diabetes Research and Clinical Practice, 87 (2010): 4-14.

Suciadi, A., S. 2003. Menguasai Pembuatan Animasi dengan Flash. Jakarta: PT Elex Media Komputindo

Tjiptono, F. 2011. Prinsip - Prinsip Total Quality Service. Yogyakarta: Andi.

Waryanto, N. H. 2005. Modul Teknik

Pembuatan Media Pembelajaran Interaktif dengan Macromedia Flash. Yogyakarta: Laboratorium Komputer, Jurusan Pendidikan Matematika Fakultas Matematika dan Ilmu Pengetahuan Alam, Universitas Negeri Yogyakarta.

Wena, M. 2011. Strategi Pembelajaran Inovatif Kontemporer. Jakarta: Bumi Aksara.

Wild, S., Roglic, G., Green, A., Sicree, R. \& King, H. 2004. Global prevalence ofdiabetes: estimates for the year 2000 and projections for 2030. Diabetic Care, 27(2004):1047-1053.

Wiryowidagdo, N. 2002.

Epidemiologi. Makassar: Lembaga PenelitianUniversitas Hasanudd in. 